\title{
APROPRIAC̣ÃO DISCURSIVA DE MODELOS DE FORMAC̣ÃO DOCENTE EM TRABALHOS DE CONCLUSÃO DE UM MESTRADO PROFISSIONAL EM ENSINO DE FÍSICA
}

\author{
Josiane de Souza* \\ Flavia Rezende** \\ Fernanda Ostermann***
}

RESUMO: Este artigo teve como objetivo investigar em três trabalhos de conclusão a apropriação discursiva do modelo de formação docente com o qual o mestrado profissional em ensino de física da UFRGS se compromete. Inicialmente, depreendemos, por meio de uma análise bakhtiniana da proposta inicial do curso e de seu currículo - considerados contexto extraverbal do objeto de análise -, que o modelo de formação propagado é o do especialista técnico. Em seguida, a análise bakhtiniana dos trabalhos nos permitiu inferir a forma como os professores-alunos se apropriam desse discurso, quando, por exemplo, apresentam referenciais teóricos desvinculados do produto educacional proposto, não consideram a realidade educacional da escola ou se pautam apenas pelo discurso oficial ou por testes internacionais de aprendizagem.

Palavras-chave: Mestrado profissional. Análise bakhtiniana. Formação de professores.

\section{APROPIACIÓN DISCURSIVA DE MODELOS DE FORMACIÓN DOCENTE EN TRABAJOS DE CONCLUSIÓN DE UNA MAESTRÍA PROFESIONAL EN ENSEÑANZA DE LA FÍSICA}

Resúmen: Este trabajo tiene el objetivo de investigar, en tres trabajos de conclusión, la apropiación discursiva del modelo de formación docente con el cual la Maestría Profesional en Enseñanza de la Física de la UFRGS se compromete. Inicialmente, deprendemos, por medio de un análisis bakhtiniano de la propuesta inicial del curso y de su currículum, considerado como contexto extra-verbal del objeto de análisis, que el modelo de formación es el del especialista técnico. Enseguida, el análisis bakhtiniano de los trabajos permitió inferir la forma como los profesores-alumnos se apropian de ese discurso, cuando, por ejemplo, presentan referenciales teóricos desvinculados al producto educacional propuesto, no consideran la realidad educacional de la escuela o se basan solamente en el discurso oficial o por testes internacionales de aprendizaje.

Palabras clave: Maestría profesional. Análisis bakhtiniano. Formación de profesores.

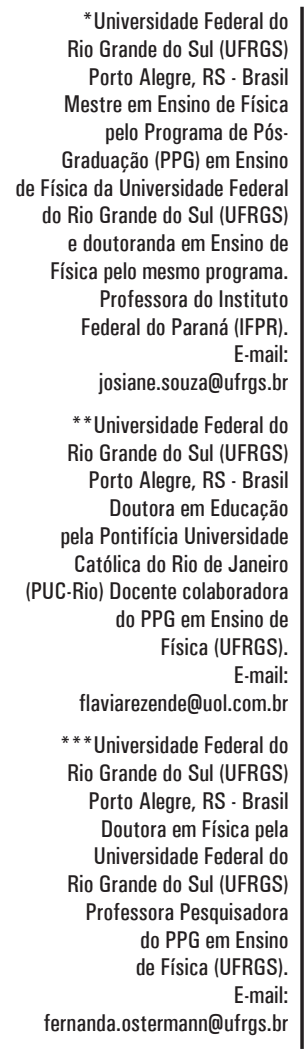

DOI - http://dx.doi.org/10.1590/1983-21172016180208 


\section{DISCURSIVE APPROPRIATION OF TEACHING TRAINING MODELS IN CONCLUSION WORKS OF A PHYSICS TEACHING MASTER}

ABSTRACT. This paper investigates, in three dissertations, the discursive appropriation of the teacher training model that the Professional Master in Physics Teaching at UFRGS promotes.First of all we performed a Bakhtinian analysis of the course's initial proposal and its curriculum, considered as extra verbal-context, from which we were able to infer that this training model is technical specialist. In the following, also by means of the Bakhtinian analysis, we were able to infer the way that teachers-students appropriate of this model, when, for example, the theoretical framework isn't articulated to the educational product developed, disregarded from real school's educational needs, or it is based on official educational discourse and international learning tests. Keywords: Professional master's degree. Bakhtin analysis. Teacher education. 


\section{INTRODUC̣ÃO}

A temática da formação de professores, que engloba como objetos de pesquisa as formações inicial e continuada de professores, vem se constituindo, desde a década de 90, como a mais profícua no âmbito da pesquisa em educação em ciências no Brasil. Essa produção, porém, divide-se de forma bastante desigual entre a formação inicial e a continuada, sendo a primeira muito mais pesquisada e discutida do que a segunda.

Tendo-se em vista a importância e a abrangência dos cursos de Mestrado Profissional (MP) na área de ensino de ciências e matemática ${ }^{1}$, em contraponto à pouca atenção que a academia tem dado a essa modalidade de formação continuada, impõem-se como necessários trabalhos que se voltem para questões do MP no âmbito da atual área de ensino da Coordenação de Aperfeiçoamento de Pessoal de Nível Superior (Capes). Considerando o mestrado profissional como objeto do presente estudo, primeiramente, realizamos um levantamento bibliográfico sobre o tema formação continuada em periódicos nacionais e internacionais da área de ensino no período entre 2009 e 2013. Pudemos constatar que a discussão sobre a formação continuada aparece em vários artigos ${ }^{2}$ da área, mas que isso ainda se dá de forma muito inconsistente. O próprio conceito de formação continuada apresenta ambiguidade, já que se está longe de chegar a um consenso quanto à sua finalidade. Essa falta de unanimidade pode e deve gerar discussões e reflexões para que cada vez mais pensemos e reformulemos essa modalidade de formação.

Muitos dos trabalhos sobre a formação continuada publicados no Brasil e em outros países atribuem aos professores a responsabilidade sobre a melhora da qualidade da educação. Essa melhora, supostamente adquirida através da formação, tem vários objetivos: sanar problemas de realocação de professores (LORENZO, 2008), melhor qualificar docentes em questões didáticas, metodológicas ou específicas de cada conteúdo (DARROZ et al., 2013; CHAILE; JAVI, 2013) ou ainda cumprir demandas governamentais ou de órgãos internacionais de fomento (BAPTISTA; FREIRE, 2011). Nos artigos pesquisados, a realidade escolar e outras questões que envolvem a qualidade do ensino não são discutidas. Apenas um dos trabalhos (LAIUS; RANNIKMÄE, 2011) atribui algum significado ao conceito de qualidade, o qual se resume ao alcance de boas notas por estudantes num teste internacional de avaliação. É importante notar que a discussão sobre para que e para quem serve a educação, essencial para definirmos o que é qualidade, está ausente dos trabalhos analisados. Afinal, falar de qualidade sem atribuir-lhe um significado pode configurar tanto um artifício de convencimento e um recurso para agradar à maioria dos ouvintes como uma falta de entendimento do próprio autor a respeito dessa questão.

Outro ponto que se relaciona com os objetivos de ser e fazer educação é o modelo de prática e formação eleito por cada autor. Corroborando os dados encontrados por Slongo, Delizoicov e Rosset (2010), vários autores trazem o termo reflexão como um objetivo da formação continuada, apresentando-o de variadas formas: como reflexão sobre a prática (AMORIM; SOUZA; TRÓPIA, 2010), prática reflexiva (LOPES et al., 2011) e reflexão crítica (POMBO; COSTA, 2009). No entanto, nenhum dos artigos se preocupa em definir esses termos, deixando sua interpretação à mercê do leitor. 
A reflexão sobre a prática, ainda que não definida, parece ser uma das principais finalidades pretendidas por muitos pesquisadores para a formação continuada. Entretanto, o modelo de formação com viés tecnicista, com alto índice de rejeição nos artigos encontrados, parece ainda não ter sido superado nos processos formativos (NERY; MALDANER, 2012). Esse viés vem sendo fomentado e propagado pelos cursos de MP em ensino no Brasil através do currículo e dos trabalhos de conclusão de curso, os quais, em geral, são voltados para a academia e desvinculados da realidade docente (OSTERMANN; REZENDE, 2009). Outro aspecto destacado pelas autoras é que, apesar do visível crescimento do interesse dos pesquisadores pela temática da formação continuada, os cursos de MP ainda não se configuram expressivamente como tema de pesquisa, aparecendo como objeto de estudo em apenas três dos trabalhos verificados.

Por ser pioneiro na área de ensino de ciências e matemática, o Mestrado Profissional em Ensino de Física (MPEF) do Instituto de Física da Universidade Federal do Rio Grande do Sul foi escolhido como nosso objeto de estudo. A pesquisa de Schäfer (2013) e os estudos de Schäfer e Ostermann (2013a, 2013b) tornam-se assim, importantes, já que foram realizados nesse contexto. As autoras buscaram pesquisar qual o impacto desse curso sobre a prática docente (SCHÄFER; OSTERMANN, 2013a) e sobre a autonomia profissional dos professores, cursistas ou egressos (SCHÄFER; OSTERMANN, 2013b). As autoras fizeram uma análise bakhtiniana dos discursos produzidos por 20 alunos (cursistas, os quais elas denominam alunos-professores, e egressos) do MPEF a partir de uma entrevista semiestruturada. Os alunos-professores e os egressos relataram que o curso de MPEF contribuiu para a renovação das metodologias e estratégias didáticas de sala de aula, mas eles percebem um grande distanciamento entre a realidade escolar que vivem e a formação que obtiveram.

A prática desses docentes, segundo Schäfer e Ostermann (2013a), está impregnada de indícios do modelo de professor especialista técnico definido por Contreras (2012). Os docentes egressos desses cursos, influenciados durante toda a sua formação por modelos de professores geralmente racionalistas técnicos, acabam reproduzindo-os em sua prática (SCHÄFER; OSTERMANN, 2013a, 2013b). As autoras afirmam que "a formação obtida no MP representa um reforço às situações vivenciadas pelos alunos-professores nas escolas, como aceitação dos regulamentos burocráticos e o distanciamento em relação ao sentido da profissionalidade" (SCHÄFER; OSTERMANN, 2013b, p.310).

Dada a relevância de se realizarem pesquisas sobre os cursos de mestrado profissional e instigadas pelos resultados já conquistados em relação ao MP em ensino de física da UFRGS, tivemos vários questionamentos: Será esse um programa comprometido com o modelo da racionalidade técnica? Seu currículo fornece requisitos para tal? E como os docentes em formação assumem, em seu trabalho de conclusão, os compromissos que são do programa? Para investigar essas questões, nós nos apoiamos em dois quadros teóricos: na discussão sobre a formação docente proposta por Contreras (2012) e na filosofia da linguagem de Bakhtin, que nos ajudou a analisar os dados linguísticos coletados na pesquisa. Com esse suporte teórico, partimos para a avaliação das relações entre os objetivos e os compromissos aos quais o programa de MP da UFRGS está atrelado e os trabalhos de conclusão de curso elaborados por professores-alunos desse curso. 


\section{MODELOS DE FORMAÇÃO DOCENTE SEGUNDO CONTRERAS}

Ao tomarmos como objeto de pesquisa processos formativos docentes, não podemos deixar de nos questionar sobre as ideologias e visões acerca do ensino assumidas e propagadas por eles. Quando nos atentamos para todos os componentes de um curso de formação continuada, notamos que, de forma tácita, concepções teóricas, metodológicas, epistemológicas, políticas, sociais etc. são fomentadas, na maioria das vezes, a partir de sua naturalização institucional. Assim, para se entender o processo formativo como um todo e se compreender o perfil docente de formação, torna-se necessária essa perspectiva que desnaturaliza eventos, trazendo-os para a discussão.

Para Contreras (2012), a problematização da formação docente passa pelo entendimento do conceito de profissionalidade, o qual se refere às qualidades da prática profissional dos professores em função do que requer o trabalho educativo. $\mathrm{O}$ autor não apenas descreve o desempenho do trabalho de ensinar, mas expressa valores e pretensões que se desejam alcançar e desenvolver na profissão. A profissionalidade pode ser mais bem entendida através de suas três dimensões: obrigação moral, compromisso com a comunidade e competência profissional. A dimensão da obrigação moral está relacionada com o fato de que o ensino supõe um compromisso de caráter moral situado acima de qualquer obrigação contratual que possa ser estabelecida (SOCKET'T apud CONTRERAS, 2012). Os docentes, além de se comprometerem com o desenvolvimento acadêmico dos estudantes, inevitavelmente, envolvem-se com a evolução pessoal de seus alunos. No entanto, a moralidade não é um fato isolado, mas, sim, um fenômeno social produto de nossa vida em comunidade, na qual é preciso resolver problemas que afetam as pessoas e seu desenvolvimento. E a solução das questões precisa elucidar o que é moralmente adequado para cada caso (CONTRERAS, 2012).

Estabelecemos, assim, outra dimensão da profissionalidade: o compromisso com a comunidade. Ou seja, a prática profissional docente não é isolada, centrada apenas nas crenças e nos ideais do professor, mas é constituída de forma partilhada entre o docente e a comunidade. Nesse sentido, tanto ele tem a responsabilidade de compartilhar suas discussões, práticas, problemas, princípios etc. como a comunidade deve participar das decisões sobre o ensino.

Nessa perspectiva, as competências profissionais transcendem o sentido puramente técnico do recurso didático. Elas são um elemento complexo que combina habilidades, princípios e consciência do sentido e das consequências das práticas pedagógicas. Para Contreras (2012), os professores desenvolvem sua competência profissional reconhecendo sua capacidade de ação reflexiva e de elaboração de conhecimento em relação ao conteúdo de sua profissão e aos contextos que condicionam sua prática para além da aula. Dessa forma, o conhecimento atribuído a essa dimensão é elaborado e reelaborado a partir de trocas, experiências e intercâmbios entre os docentes, tornando-se produto de diferentes tradições e posições pedagógicas que emergem de distintas vivências e realidades.

$\mathrm{O}$ autor apresenta três modelos de compreensão da prática docente que, de acordo com ele, delineiam tendências básicas defendidas teoricamente e oferecem uma maneira mais matizada e complexa do que a autonomia profissional docente pode significar. 


\section{0 especialista técnico}

A concepção de que o docente é um especialista técnico é pautada, segundo Contreras (2012), no modelo de racionalidade técnica. A ideia básica desse modelo é que a prática consiste na solução instrumental de problemas mediante a aplicação de um conhecimento teórico e técnico, previamente disponível, que procede da pesquisa científica (CONTRERAS, 2012). Schein (apud CONTRERAS, 2012) identificou três componentes essenciais do conhecimento profissional racionalista técnico: a ciência ou disciplina básica, a ciência aplicada ou engenharia e a habilidade e atitude. A primeira compreende todo o escopo do conhecimento sobre o qual a prática se apoia e se desenvolve, a segunda engloba os métodos e procedimentos empregados para diagnosticar e resolver os problemas, e a terceira se relaciona com a atuação concreta a serviço do cliente. Nesse modelo, as práticas docentes ficam submetidas ao conhecimento estabelecido, e concretiza-se uma hierarquização na relação entre prática e conhecimento, produzindo reconhecimento e status acadêmico diferenciado para os produtores de conhecimento em relação aos professores. Além da prática, a formação docente também é subordinada à hierarquização curricular que, em geral, subordina disciplinas práticas às disciplinas teóricas, relegando as disciplinas de cunho pedagógico e didático ao fim do curso.

Outro ponto relevante desse modelo é a tentativa de estudar ações humanas através do conhecimento empírico-analítico, cujo interesse constitutivo é o técnico, isto é, a ação sobre os objetos para obter deles os resultados desejados (CONTRERAS, 2012, p.104). O docente passa a agir para alcançar os fins pretendidos, sem questionar o surgimento desses objetivos ou os contextos humanos e sociais em que estão atuando, tampouco a consequência de sua prática sobre eles. O domínio técnico atribuído ao docente nessa perspectiva está relacionado ao conhecimento dos procedimentos adequados de ensino e à sua aplicação inteligente. Esses procedimentos são elaborados por especialistas, e o professor tem acesso a eles por meio das formações inicial e continuada.

O autor assinala que a sala de aula é, no entanto, um espaço interativo imprevisível, onde são desenvolvidas, questionadas e problematizadas, pelos alunos e docente, questões para além da disciplina específica. A necessidade de resgatar a base reflexiva na atuação profissional, com o propósito de entender como realmente se abordam as situações problemáticas da prática, leva Contreras (2012) ao modelo docente do profissional reflexivo.

\section{0 professor reflexivo}

A ideia de profissional reflexivo foi desenvolvida por Schön (apud CONTRERAS, 2012) com intuito de dar conta da forma com a qual os profissionais enfrentam aquelas situações que não se resolvem por meio de repertórios técnicos; aquelas atividades que, como o ensino, caracterizam-se por atuar sobre situações incertas, instáveis, singulares e nas quais há conflito de valor (CONTRERAS, 2012). Assim, ações são realizadas através de um conhecimento interiorizado e implícito na própria ação, e nem sempre consciente. Ele não precede a ação, mas está tacitamente personificado nela e, portanto, é definido como conbecimento na ação. Outra característica 
importante desse modelo é que ele supõe uma reflexão sobre a maneira com que habitualmente entendemos a ação que realizamos, que emerge para podermos analisála em relação à situação na qual nos encontramos e reconduzi-la adequadamente. Schön (apud CONTRERAS, 2012) chama essa característica de reflexão na ação.

Nesse modelo, o professor não está à margem da discussão pública sobre as finalidades do ensino e de sua organização. Ao contrário, encontra-se bem no meio dela (CONTRERAS, 2012). Sua autonomia docente acaba se realizando no contexto dos elementos que intervêm na reflexão e na avaliação das questões ideológicas e sociais que a comunidade impõe. O docente não pode fazer escolhas sem ponderar as ideias e as demandas da comunidade em que está inserido. Suas ações são pautadas no equilíbrio entre seu juízo sobre as coisas e o compromisso social que lhe compete.

O professor reflexivo encontra limites ao se defrontar com as características da instituição educacional na qual atua. O excesso de responsabilidades, caracterizado, por exemplo, pela grande quantidade de horas de trabalho e pela insegurança causada pelo medo de críticas e de sanções, leva os docentes a condicionarem sua reflexão à sala de aula, a se isolarem e a atribuírem a culpa sobre as questões desconfortáveis aos contextos imediatos. Nessas condições, surge a necessidade de se dispor de uma teoria crítica, que permita aos professores perceberem qual a sua situação (CONTRERAS, 2012). Tal teoria dá origem ao modelo do intelectual crítico, discutido na seção a seguir.

\section{0 professor intelectual crítico}

O modelo de formação do professor intelectual crítico é construído por Contreras (2012) sob dois pilares: o docente como intelectual, defendido por Giroux (apud CONTRERAS, 2012), e o crítico-reflexivo, proposto pelo próprio autor.

A ideia do professor como intelectual, sugerida por Giroux (apud CONTRERAS, 2012), oferece um programa de compreensão e análise de uma concepção do que devem ser os professores. Essa concepção está ligada à visão de autoridade emancipatória, de liberdade, igualdade e democracia, que orienta os docentes a construírem um ensino dirigido à formação de cidadãos críticos e reflexivos. Nesse contexto, as escolas se tornam esferas públicas democráticas, ou seja, lugares onde os alunos aprendem e lutam coletivamente por condições que propiciem a liberdade individual e a capacitação para a atuação social (CONTRERAS, 2012). Assim, os docentes precisam ter claros os referenciais políticos e morais sob os quais constituem sua autoridade de ensino, já que estão comprometidos com a transformação social, por meio da capacitação de pensar e agir criticamente. Esse comprometimento remete ao que Giroux (apud CONTRERAS, 2012) denomina intelectual transformador, profissional que, além de obter um controle maior sobre as condições de seu trabalho e ensinar pedagogia crítica, deve abrir a prática educativa a outros grupos e práticas sociais compromissados com a contestação popular ativa, bem como a todos os setores que devem ter voz ativa na comunidade (CONTRERAS, 2012).

No entanto, para Contreras (2012), Giroux esquece, pelo menos em sua obra, que os professores estão presos aos limites de suas salas de aula e não discute como os docentes poderiam, na realidade, construir essa visão crítica em relação à 
sua profissão. A fim de dar conta desse quesito, Contreras (2012) recorre à reflexão crítica, que, para ele, facilita a ligação de uma concepção libertadora de prática de ensino com o processo de emancipação dos próprios professores. A reflexão crítica permite analisar e discutir, além das questões da prática, as estruturas institucionais em que os docentes trabalham, e auxilia na exploração da natureza social e histórica tanto da atuação dos docentes como atores das práticas institucionalizadas da educação quanto da relação entre o pensamento e a ação educativos (CONTRERAS, 2012). Assim que começa a desenvolver a reflexão crítica, o professor visualiza seu mundo de forma diferente, inclusive investigando os porquês de determinadas regras e ações. Desse modo, os docentes passam a ter um tipo de emancipação das visões acríticas que sustentavam sua prática, encabrestada pelo senso comum, construído de formas política, histórica e social. Ao desvelarem a origem sóciohistórica da educação, descobrindo para que e a quem ela serve, os professores começam a realizar uma ação transformadora, dirigida a combater a irracionalidade e a injustiça existentes no ensino e nas instituições que o sustentam.

\section{QUADRO TEÓRICO-METODOLÓGICO}

Nossa pesquisa é um estudo qualitativo, com o qual buscamos examinar o modelo formativo do MPEF da UFRGS por meio da análise da proposta inicial do curso, do currículo e de uma amostra de trabalhos de conclusão de curso produzidos por professores-alunos desse contexto. Na busca pela compreensão das circunstâncias da formação, partimos do princípio de que estamos lidando com uma realidade sociocultural multifacetada e moldada necessariamente pela linguagem.

Assim, optamos por fundamentar nossa pesquisa em alguns conceitos da filosofia da linguagem desenvolvida pelo filósofo russo Mikhail Bakhtin. Esse autor entende que os diversos campos da atividade humana estão ligados ao uso da linguagem e que essa é dialógica e social. Nessa perspectiva, a linguagem é fenômeno social, histórico e ideológico, elemento de comunicação. Por consequência, ela "não poderá jamais ser compreendida e explicada fora desse vínculo com a situação concreta" de produção (BAKHTIN, 2008, p. 124). Dessa forma, a filosofia de Bakhtin se torna uma aliada teórica na interpretação e na análise de discursos à medida que nos permite investigar além do que é dito, levando em conta o contexto de produção dos enunciados. Esse aspecto é de extrema importância na elaboração de nosso trabalho, já que escolhemos estudar documentos e trabalhos produzidos em um curso de MP em ensino de física, considerado um contexto sociocultural, no qual, portanto, a linguagem desempenha papel fundamental.

A linguagem é a forma com que o ser humano se expressa e se legitima. É a partir dela que o homem consegue se comunicar com o outro e com o mundo. Voloshinov $^{3}$ (1981[1930]) afirma que a linguagem é um produto da vida social e que seu desenvolvimento segue a evolução da vida social e se encontra em um perpétuo devir. Para Bakhtin (2010), os enunciados (orais e escritos), concretos e únicos,emanam dos integrantes de uma ou de outra esfera da atividade humana e são caracterizados pelo conteúdo (temático), por seu estilo verbal e, sobretudo, por sua construção composicional.Esses três componentes estão indissoluvelmente 
ligados ao todo do enunciado e são igualmente determinados pela especificidade de um algum campo da comunicação. Mesmo que cada enunciado particular seja individual, cada campo de utilização da língua elabora seus tipos relativamente estáveis de enunciados, os chamados gêneros do discurso (BAKHTIN, 2010).

Quando o autor profere um enunciado, ele tem um destinatário suposto, que pode estar presente fisicamente ou nãoe está localizado em espaço e tempo definidos e em uma esfera da atividade humana. O conteúdo temático do enunciado é escolhido de acordo com a ideia que o locutor quer passar e para quem ele imagina que vai falar.

A construção composicional, da mesma maneira, varia conforme a esfera da atividade na qual o enunciado é produzido. Assim, o falante vai construir seu discurso segundo as expectativas dos ouvintes integrantes da esfera em questão. Portanto, nenhum enunciado pode ser considerado uma combinação absolutamente livre de formas da língua (BAKHTIN, 2010).

Os estilos de linguagem, de acordo com Bakhtin (2010), não são outra coisa senão estilos de gênero de determinadas esferas da atividade humana e da comunicação. $O$ destinatário suposto de uma dada esfera também interfere na escolha do estilo verbal do enunciado pelo locutor. Apesar de todo enunciado ser individual e refletir, por vezes, a individualidade do falante, o estilo do enunciado ainda é direcionado e moldado ao ouvinte. As três características citadas acima, porém, também são utilizadas para outras unidades da língua (parágrafo, frase, oração). O que de fato demarca a teoria de Bakhtin e o enunciado como unidade analítica discursiva são seus aspectos únicos: alternância de sujeitos, conclusibilidade, responsividade e direcionalidade.

Bakhtin (2010) afirma que o enunciado não é uma unidade convencional, mas uma unidade real, precisamente delimitada pela alternância dos sujeitos do discurso, que ocorre porque o falante dá indícios de que está terminando sua fala, suscitando resposta e indicando que o outro pode falar. Bakhtin (2010) denomina cada enunciação proferida pelos falantes no diálogo de réplica e afirma que cada réplica, por mais breve e fragmentária que seja, possui conclusibilidade. Logo, essa está intimamente ligada à alternância de sujeitos do discurso, já que, para que haja a mudança, o falante deve dar indícios de que falou tudo o que queria em dado momento ou sob dadas condições.

Todo enunciado, para se constituir, necessita de um falante, que o enuncia, e de um ouvinte, que o interpreta. Concordância, objeção, execução etc. vêm de uma atitude responsiva ao enunciado, iniciada no instante em que o ouvinte começou a interpretá-lo. Assim, podemos notar que nenhuma interpretação de enunciado é livre de juízo de valor ou do posicionamento do ouvinte, diferente do que ocorre com a interpretação de outras unidades da língua.

Chegamos, assim, à terceira característica do enunciado: a responsividade. Além de o enunciado ter o caráter responsivo ao ser proferido pelo falante e interpretado pelo ouvinte (responsividade entre o falante e o ouvinte), há a responsividade entre enunciados. Para Bakhtin (2010), cada enunciado é um elo na corrente complexamente organizada de outros enunciados, ou seja, cada enunciado responde a outros enunciados que já foram proferidos anteriormente. O falante não é o primeiro a emitir opiniões acerca de determinado assunto, mesmo que esse seja uma novidade, e os argumentos utilizados para a elaboração 
da ideia foram empregados anteriormente. O enunciado do falante está, em maior ou menor grau, respondendo aos enunciados antecedentes, seus e de outros falantes, e precedendo, de forma a tentar inferir, os enunciados posteriores. A responsividade, seja entre enunciados ou entre falante e ouvinte, dá-se através de ideias (conteúdo temático), do gênero discursivo utilizado e da estilística e da construção escolhidas pelo falante.

Por fim, a última componente: a direcionalidade. Ao construir o enunciado, o falante o está direcionando a um suposto destinatário que compõe determinada esfera da atividade humana. O direcionamento é, portanto, o componente que faz com que o enunciado exista, constitua-se, pois, ao direcionar seu discurso para determinado ouvinte, o falante molda o enunciado considerando a responsividade, $\mathrm{O}$ estilo, a construção e o gênero adequados ao destinatário. Então, sem se levar em conta a relação entre o falante e o ouvinte e seus enunciados, é impossível compreender o gênero ou o estilo do discurso, bem como suas nuances e peculiaridades.

O enunciado é elaborado num processo que defronta, responde e direciona outros enunciados. Logo, trazer à tona o contexto extraverbal é importante para se entenderem as relações dialógicas estabelecidas. Dessa interação constante e contínua entre os enunciados e entre o falante e o ouvinte surge o que Bakhtin (2010) chama de processo de assimilação. Para o autor, o discurso é impregnado de palavras dos outros, que trazem consigo sua expressão e seu tom valorativo, os quais são assimilados, reelaborados e reacentuados cada vez que o falante profere seu enunciado (BAKHTIN, 2010).

O objetivo da assimilação da palavra de outrem adquire um sentido profundo e relevante no processo de formação ideológica do homem (BAKHTIN, 2002). A palavra de outrem pode surgir em duas categorias: a autoritária ou a interiormente persuasiva, e é no conflito e nas inter-relações entre elas que, frequentemente, a história da consciência individual é determinada. A simples interpretação ou manipulação do discurso se dá porque a palavra autoritária gera um discurso autoritário, que se impõe, exigindo reconhecimento incondicional, e não uma compreensão e uma assimilação livre, com nossas próprias palavras (BAKHTIN, 2002). Já a apropriação e a subversão do discurso são possíveis quando o discurso internamente persuasivo é mais aberto e se configura na palavra persuasiva, que é comumente metade do falante e metade de outrem. A apropriação se dá, pois a palavra é interpretada pelo ouvinte e continua a desenvolver-se livremente na consciência dele, adaptando-se aos novos materiais, às novas circunstâncias, aos novos contextos etc. (BAKHTIN, 2002).

\section{Um dispositivo analítico bakhtiniano}

Para auxiliar nossa análise bakhtiniana do discurso, utilizaremos um dispositivo elaborado por Veneu, Ferraz e Rezende (2015). Esse dispositivo é composto pelas quatro etapas descritas a seguir de forma articulada com o objetivo deste trabalho e leva em consideração, principalmente, dois aspectos da teoria de Bakhtin: o primeiro é que a análise dos fenômenos linguísticos deve ser feita tendo em vista as condições concretas em que eles se realizam, e o segundo, que a unidade de comunicação verbal é o enunciado (em oposição às unidades da língua, tais como a frase e a oração). 
Identificação do enunciado: o conceito de enunciado nos permite concluir que a própria alternância entre os sujeitos falantes já é suficiente para identificá-lo, ou seja, o enunciado inicia no momento em que o falante toma a palavra para si e finaliza quando que ele termina o que gostaria de dizer, permitindo que o outro também fale.

Leitura preliminar do enunciado: o objetivo desta etapa é estabelecer o primeiro contato com os enunciados no sentido de identificar preliminarmente seus elementos linguísticos (estilo, construção composicional, unidade temática, relação com o falante e outros participantes, conclusibilidade) e fazer uma articulação prévia entre o material linguístico, as questões de pesquisa e os conceitos bakhtinianos.

Descrição do contexto extraverbal: a partir da leitura preliminar e da articulação prévia das questões de pesquisa com os conceitos bakhtinianos é realizada uma investigação do contexto extraverbal para detectar quais dos vários elementos contribuirão mais para a análise. Esses elementos são, então, descritos e articulados com vistas a definir o horizonte espacial comum dos interlocutores, bem como seu conhecimento, sua compreensão e sua avaliação da situação, além do momento social e histórico em que ocorre, da rede de enunciados a que se relacionam etc.

Análise do enunciado: consiste em articular os elementos linguísticos (estilo, construção composicional, conteúdo temático, relação com o falante e outros participantes, conclusibilidade), o contexto extraverbal e os conceitos bakhtinianos envolvidos nos objetivos do estudo.

\section{Procedimentos de análise}

\section{Identificação dos enunciados}

Nosso objeto de análise é uma amostra das dissertações e dos produtos educacionais desenvolvidos no MPEF da UFRGS, programa pioneiro nessa modalidade no Brasil. Para obterem grau de mestre nesse curso, os docentes devem, necessariamente, desenvolver um produto educacional, aplicá-lo em sala de aula e produzir e defender uma dissertação acerca do trabalho feito. Cada dissertação configura uma obra escrita e, juntamente com cada produto (texto de apoio, hipermídia ou página da web), forma um enunciado, ainda que as páginas da web possam ter mais de uma aba. As dissertações, com os produtos, são obrigatórias para a obtenção do título de mestre e do material concreto (de fácil acesso) desenvolvido por todos os mestrandos, independentemente de qual seja o produto educacional. Para chegarmos à identificação dos enunciados a serem analisados, inicialmente fizemos um mapeamento de todos os trabalhos produzidos pelo MPEF da UFRGS. Escolhemos utilizar a denominação "trabalho de conclusão", pois se trata da dissertação mais o produto educacional produzido. Mapeamos o ano de defesa das dissertações, a natureza do produto desenvolvido, o nível de educação ao qual ele se destina, o caráter da escola de aplicação e os referenciais teóricos, metodológicos e epistemológicos.

Até 8 de dezembro de 2014, o MPEF formou 91 mestres em ensino de física ${ }^{4}$, sendo que há 75 dissertações disponíveis para consulta no site do MPEF da UFRGS $^{5}$ e 57 com produtos acessíveis. ${ }^{6}$

Os links existentes para consulta dos produtos são de quatro tipos: texto 
de apoio, página da web, hipermídia e outros textos. São 86 links disponíveis para produtos, sendo que alguns trabalhos possuem mais de um link relacionado a eles. São 38 textos de apoio, 25 hipermídias, 18 páginas da web e 5 outros textos.

Dos 75 trabalhos que possuem dissertação disponível, apenas três não citam um referencial teórico explicitamente; os outros mencionam um ou mais autores, sendo Ausubel (47 dissertações) e Vygotsky (39 dissertações) os mais referidos.

Quanto ao nível do ensino a que se dedicam, 40 trabalhos são voltados para o ensino médio, 11 para o superior, 10 para o fundamental, 7 para o ensino técnico, 3 para o magistério/normal, 2 para o EJA, 1 para ensinos superior e médio, 1 para médio e técnico e 1 para médio e fundamental.

De todos os trabalhos, apenas um não foi aplicado, pois se referia a uma análise e ao desenvolvimento de uma disciplina voltada ao Ensino Superior. Dos aplicados, 29 foram em escolas de caráter privado, 24 em escolas de caráter público estadual ou municipal, 20 em escolas federais (institutos federais, centros federais de educação e tecnologia, colégios de aplicação e colégios militares), 2 em escolas públicas e privadas e 1 em uma escola de caráter público/privado.

Optamos, então, por escolher três trabalhos cujas dissertações e produtos educacionais estivessem disponíveis na página do MPEF da UFRGS. A fim de não nos concentrarmos em uma fase particular de desenvolvimento do curso, selecionamos três trabalhos finalizados em três distintos períodos. Assim, elegemos trabalhos orientados por diferentes orientadores, com formação diferenciada entre si, e defendidos em anos diversos:

- um em 2004 (ano de formação da primeira turma do MPEF), orientado por um professor com formação e produção na área de ensino de física; - outro em 2009, orientado por um professor com formação e produção na área de física;

- outro em 2014, orientado por dois professores, um com formação na área de física,mas com produção em ensino de física, e outro com formação e produção na área de ensino de física.

Devido ao fato de os trabalhos com produtos de natureza texto de apoio serem os mais numerosos, preferimos adotá-los.

\section{Leitura preliminar dos enunciados}

Nesta etapa da análise, realizamos uma leitura preliminar, sem muito aprofundamento das questões analíticas, dos três trabalhos escolhidos, considerados enunciados. Denominaremos esses materiais como trabalho do professor-aluno 1, trabalho do professor-aluno 2 e trabalho do professor-aluno 3, e preservaremos os nomes dos autores e dos orientadores.

O trabalho 1, finalizado em 2004, tem como foco o Ensino Fundamental. $\mathrm{O}$ autor buscou desenvolver estratégias didáticas que facilitassem a inclusão da física no currículo das primeiras séries do Ensino Fundamental. Para isso, utiliza conceitos de Piaget, Vygotsky e Vergnaud como fundamentação teórica e relaciona conceitos de ensino por pesquisa e atividades do Projeto Mão na Massa como fundamentação metodológica. A implementação do trabalho 1 se deu em duas escolas particulares, no ano de 2003, e, segundo o próprio autor da dissertação, 
os resultados obtidos através dessa aplicação foram positivos, pois conseguiram desenvolver nas crianças a capacidade de observar fenômenos e a curiosidade pela pesquisa e pelos experimentos científicos.

O trabalho 2, finalizado em 2009, tem como foco o Ensino Médio e a utilização da história da física como facilitador para a aprendizagem da mecânica de fluidos. O autor optou por fundamentar teoricamente seu trabalho em conceitos de Ausubel e Novak e, ao longo de seu texto, buscou investigar tanto pesquisas e estratégias já desenvolvidas acerca da utilização da história da ciência no ensino quanto a forma como os livros didáticos, usualmente utilizados nas escolas, abordam a mecânica de fluidos e a própria história da ciência. Essa proposta foi implementada em quatro turmas do segundo ano de uma escola particular, entre agosto de 2007 e julho de 2008. De acordo com o autor, a aplicação do trabalho 2 obteve êxito, pois os estudantes se tornaram mais predispostos a aprender, além de ficarem mais participativos e entusiasmados nas aulas.

O trabalho 3, finalizado em 2014, apresenta uma proposta para introdução do uso de tecnologias no ensino de física experimental em um curso de licenciatura em física. $\mathrm{O}$ autor não explicita nenhum referencial teórico, mas sustenta seu trabalho em uma revisão bibliográfica sobre o uso do computador no ensino de física e nos aspectos legais, bem como sobre a utilização de tecnologias no ensino, trazida pelos documentos oficiais (LDB, PCN e documentos do PIBID). A proposta foi praticada em uma universidade particular, e o autor assume que obteve sucesso, já que houve engajamento e interesse dos alunos participantes das atividades.

\section{O contexto extraverbal ${ }^{7}$}

O contexto extraverbal dos trabalhos de conclusão, considerados enunciados, é composto por uma parte comum a todos os alunos, como, por exemplo, o regulamento do curso, as regras administrativas e acadêmicas e os docentes das disciplinas do MPEF, e por uma parte não compartilhada, que consiste na orientação acadêmica recebida individualmente, na escola de atuação do professor-aluno e em sua formação inicial.

A parte comum do contexto extraverbal desses enunciados é composta pelos documentos legais que regem o programa de MPEF do IF da UFRGS, pelo elenco de disciplinas que compõem o currículo do MPEF e pela atuação dos docentes que ministram essas disciplinas. De fato, outros componentes também fazem parte desse contexto extraverbal, mas foi necessário fazer um recorte para conseguirmos obter informações e analisá-las no limite de tempo estipulado para a elaboração da dissertação. Assim, limitamo-nos a considerar a proposta inicial do curso do MPEF enviada à Capes em 2001 e o conjunto das disciplinas ministradas no período de 2002 a 2014.

A proposta do curso foi produzida seguindo um modelo de documento fornecido por essa agência, no qual os seguintes tópicos deveriam ser preenchidos: Histórico, Objetivos, Inserção Regional, Justificativa de Implementação, Integração com a Graduação, Infraestrutura-Laboratório, Infraestrutura-Recursos de Informática, Infraestrutura-Biblioteca, Infraestrutura-Financeira, Atividades Complementares dos Docentes, Trabalhos em Preparação, Intercâmbios 
Institucionais, Autoavaliação, Ensino a Distância e outras informações. Realizamos a análise bakhtiniana desse documento, utilizando os conceitos de responsividade e direcionalidade do enunciado, para visualizar como ele compõe o contexto extraverbal do MPEF. Entendemos que, pela alternância apresentada no documento, cada um dos referidos tópicos é um enunciado da Capes e que as respostas dos elaboradores da proposta são os enunciados a serem analisados.

Ao realizarmos a leitura preliminar dos enunciados, notamos que o texto, apesar de envolver um número grande de tópicos, é escrito em poucos parágrafos e de forma objetiva, sem argumentações mais profundas. Mesmo tendo poucas páginas, ele traz, mais de uma vez, a ideia de que não serão contratados novos professores para o MP.

Tentando recompor o contexto extraverbal dos enunciados da proposta, recuperamos o fato de que a demanda por cursos de MP surge a partir das diversas mudanças e reformulações legais sofridas pelo Ensino Superior brasileiro sob a influência das agências internacionais de financiamento. Essas reformas são evidenciadas pelas diretrizes de reformulação do Estado e da educação superior difundidas pelo Banco Mundial para os países periféricos, as quais envolvem o deslocamento da concepção de educação superior para o de educação terciária.

O Instituto de Física da UFRGS, com larga tradição em pesquisa, propôsse a criar um curso para cumprir essa demanda. Nesse momento, algumas dissertações e teses já haviam sido defendidas nesse programa, na área de ensino de física, e o IF contava com alguns professores pesquisadores em ensino. Esses tinham como objetos de pesquisa, principalmente, as Tecnologias de Informação e Comunicação (TICs) no ensino de física e a inserção de tópicos de Física Moderna e Contemporânea (FMC) no Ensino Médio. De fato, esses assuntos tinham e têm grande visibilidade na área de ensino de ciências e matemática, ou seja, são objetos facilmente aceitos pela comunidade acadêmica. A realidade escolar brasileira, no entanto, estava bem distante desses assuntos. Nessa época, as TICs eram artigo de luxo tanto nas escolas públicas quanto nas particulares, e a FMC, ainda hoje, parece uma preocupação maior para os pesquisadores do que para os docentes de nível médio. Ainda que se possa contrastar esse olhar com visões que reconhecem o papel da universidade na produção do conhecimento, percebe-se a tensão existente entre demandas escolares e a área de pesquisa em ensino.

Iniciamos a análise dos enunciados pelo item Histórico. Nele, os autores começam o texto citando a importância histórica da área de ensino de física, que integrava, na época, a pós-graduação em física da UFRGS. Em seguida, afirmam que, por já ter sólida tradição na pesquisa em ensino de física, a instituição estaria habilitada a receber um mestrado profissional nessa área.

No tópico Objetivos, os elaboradores expõem o objetivo do curso proposto:

Melhorar a qualificação profissional de professores de física do nível médio, e das licenciaturas em física ou afins, em plena atividade no sistema de ensino, em termos de conteúdos de física, de aspectos teóricos, metodológicos e epistemológicos do ensino da física, e do uso de novas tecnologias.

Percebe-se que os problemas da escola não fazem parte desse objetivo. Os 
autores utilizam o estilo de linguagem próprio das ciências da natureza em um texto objetivo e pouco argumentativo. Em termos de conteúdo, verifica-se a menção ao uso de novas tecnologias. Como salientamos, essa demanda não parte da realidade escolar, ou da realidade do professor, mas, sim, de especialistas acadêmicos que julgam ser esses os elementos necessários para aprimorar a qualificação do docente de nível médio e que, consequentemente, terão impacto na qualidade do Ensino Médio.

No item Justificativa de Implementação, os autores explicitam que o programa deve ser implantado em resposta a uma demanda da Capes e que a instituição se julga apta a atender a essa necessidade. Percebe-se, nessa justificativa, o interesse dela em apenas responder a uma solicitação oficial de fora, não sendo uma proposta almejada e legitimada pelos professores.

Em resposta ao tópico Integração com a Graduação, os autores afirmam que os mesmos professores que já atuam na licenciatura e no bacharelado em física serão os que ministrarão as aulas para o MP. Essa ideia é reafirmada no item Atividades Complementares Docentes, com ênfase na dedicação exclusiva e nas atividades complementares dos professores exclusivamente ligadas à pesquisa e à academia. Não há preocupação com a possibilidade de esses professores suprirem as necessidades específicas de um curso de MP, pois é assumido que, se eles dão aulas nos cursos de formação inicial, estão preparados também para a formação continuada. Notamos, ainda, a hierarquização suposta pelos autores ao entenderem que, se os professores trabalham com pesquisa, têm igualmente condições de atuar com professores e com as demandas do Ensino Médio, subordinando-as, assim, à agenda da academia.

Por fim, no tópico Outras Informações, são elencadas as disciplinas obrigatórias e opcionais que farão parte do currículo, contemplando a formação em física, a formação didático-pedagógica, relevante no ensino da física, a prática docente supervisionada e a elaboração de um trabalho final de pesquisa profissional. Pela escolha da ordem desses elementos, podemos supor a hierarquia de importância dada pelos elaboradores aos vários tipos de formação propostos. A formação conteudista, típica do modelo de racionalidade técnica, é a primeira e será proporcionada por disciplinas obrigatórias e opcionais. As obrigatórias são: Tópicos de Física Clássica, Tópicos de Física Moderna e Contemporânea I e II, Novas Tecnologias no Ensino de Física I e II e História e Epistemologia no Ensino de Física. Já as opcionais são: Teorias de Aprendizagem e Ensino (apesar de, na proposta, aparecer como opcional, essa disciplina sempre foi ministrada em caráter obrigatório), Ensino de Astronomia, Novas Tecnologias no Ensino de Laboratório e Física Moderna e Contemporânea: Teoria e Prática.

$\mathrm{Na}$ escolha das disciplinas, fica evidente que as obrigatórias são pautadas na pesquisa dos docentes que viriam a ministrar disciplinas no MP, e o trabalho final proposto remonta à ideia de pesquisa acadêmica. O conjunto das disciplinas é condizente com o modelo de professor racionalista técnico à medida que o currículo contempla componentes da disciplina básica, de ciência aplicada e de habilidade e atitude; esses últimos ficam nas disciplinas opcionais, enquanto os outros aparecem tanto nas disciplinas obrigatórias quanto nas opcionais. As obrigatórias acabam por abarcar, principalmente, os componentes da disciplina básica, que não condizem com o contexto escolar vigente dos docentes de nível médio. Já os componentes de habilidade e atitude ficam, exclusivamente, nas 
opcionais, sendo possível um aluno obter título de mestre em ensino de física sem cursar uma única disciplina sobre ensino e aprendizagem.

A ideia de manter o currículo fixo e bem determinado na linha em que foi proposto evidencia uma das características do racionalismo técnico, como se os problemas profissionais dos docentes de nível médio fossem apenas os que compreendem o entendimento e a aplicação de materiais em sala de aula e se essas disciplinas fossem o meio pelo qual se pode melhorar a atuação do professor.

A configuração curricular do MPEF foi alterada ao longo dos anos, sem, entretanto, perder seu caráter racionalista técnico. As disciplinas são ministradas tanto por docentes oriundos do bacharelado em física quanto pelos advindos da área de ensino de física, sem se seguir uma regra específica. As disciplinas de conteúdo básico, apesar de não serem as de maior número, são as de cunho obrigatório e ofertadas em todos ou em quase todos os semestres do curso. É o caso, por exemplo, de tópicos de física clássica e física moderna e contemporânea I e II. As disciplinas de ciência aplicada já se dividem entre obrigatórias e eletivas, mas ainda assim a frequência de oferta é alta, a exemplo de tecnologias da informação e comunicação no ensino de física I e II, que é ofertada em todos os semestres, e de física moderna e contemporânea: teoria e prática, em semestres espaçados. As disciplinas de cunho didático e epistemológico voltadas a habilidades e atitudes em sala de aula, todavia, são, em sua maioria, eletivas, e mesmo algumas obrigatórias não são disponibilizadas em todos os semestres.

\section{Contextos extraverbais individuais}

Além dos elementos compartilhados pelos docentes formadores e em formação (currículo, regulamento do curso etc.), o contexto extraverbal é composto por elementos individuais, oriundos da experiência e da vivência de cada um. Por exemplo, os locais de trabalho e da formação inicial também integram o contexto extraverbal de cada docente em formação, assim como as características da orientação. Buscamos, então, traçar um esboço do contexto extraverbal próprio de cada autor no momento em que cursavam o MPEF. Para tal, recorremos aos dados apresentados pelos autores e orientadores em seu currículo pessoal publicado na plataforma Lattes.

O professor-aluno 1 tem formação inicial em física por uma universidade pública e, no momento em que realizou o MPEF (2002-2004), atuava em uma escola particular internacional que segue os moldes das escolas dos EUA. Esse trabalho foi orientado por um pesquisador em ensino de física que é licenciado em física pela UFRGS, mestre em física, com ênfase em ensino, pela UFRGS e doutor em educação em ciências pela Universidade de Cornell, nos EUA. As principais linhas de pesquisa do orientador desse trabalho são as teorias de aprendizagem e a aprendizagem significativa de Ausubel.

O professor-aluno 2 possui formação inicial em uma universidade particular em licenciatura em física e, por alguns anos, cursou, concomitantemente ao MPEF da UFRGS (2003-2009), o mestrado em engenharia e tecnologia de materiais (2001-2004) em uma universidade particular. Enquanto fazia o MPEF, trabalhou em duas escolas particulares. O pesquisador que orientou esse trabalho é graduado em física pela UFRJ e mestre e doutor em física pela UFRGS. O 
pesquisador trabalha com física estatística e, em 2002, passou a atuar no MPEF, ministrando aulas e orientando alunos.

Já o professor-aluno 3 tem formação inicial em licenciatura em física por uma universidade particular e, enquanto cursava o MPEF da UFRGS (20112014), também fazia engenharia civil, em uma universidade particular, e atuava como monitor. Esse trabalho contou com orientador e co-orientador. O primeiro possui graduação e mestrado em física pela UFRGS e doutorado em ciências pela mesma instituição. Ao longo de sua carreira, dedicou-se à pesquisa em ensino de física direcionada à utilização das tecnologias da informação e comunicação nessa modalidade. Sua principal linha de pesquisa é a modelagem computacional no ensino de física. O coorientador é graduado em física pela UFRGS, possuindo especialização em metodologia do ensino pela Unisinos, mestrado em física, com ênfase em ensino, pela UFRGS e doutorado em educação pela PUC/RS. Suas principais linhas de pesquisa são métodos quantitativos aplicados à pesquisa, história e filosofia da ciência e tópicos gerais de física.

\section{ANÁLISE DOS TRABALHOS DE CONCLUSÃO}

A partir da análise realizada, podemos concluir que o MPEF do IF da UFRGS privilegia o modelo de formação do especialista técnico. Três pontos da proposta inicial e do currículo vigente do programa foram os mais importantes para essa conclusão: os professores que já trabalhavam na pós-graduação em física, especificamente na área de ensino de física, seriam os que ministrariam as disciplinas, subordinando, assim, o MP à pesquisa acadêmica; o trabalho final para conclusão do curso de MP é denominado trabalho final de pesquisa profissional, remetendo a um trabalho acadêmico; a grade curricular, formulada para acomodar os docentes que ministrariam aulas no MP, contempla os três componentes que, hierarquicamente, caracterizam o modelo racionalista técnico (CONTRERAS, 2012), colocando em primeiro plano as disciplinas que tratam do conteúdo específico; em segundo plano, as que abordam o conhecimento aplicado; e, em terceiro plano e de forma pouco explorada, as que versam sobre os componentes do saber do professor e as relacionadas com o fazer docente.

Para que um professor-aluno obtenha o título de mestre pelo MPEF do IF da UFRGS, ele deve elaborar um trabalho de conclusão composto por uma dissertação e por um produto educacional. Geralmente, é na dissertação que os professores-alunos trazem os objetivos e as motivações que os levaram a desenvolver tal produto. Por isso, dentro de uma perspectiva bakhtiniana do discurso, fez sentido analisarmos discursivamente ambos os elementos. Eles são completivos, tornando possível que o leitor apenas compreenda o todo do enunciado lendo um e o outro e vice-versa.

Ao examinarmos três das 94 dissertações já defendidas no MPEF, tivemos a intenção de investigar de que forma o modelo de formação docente privilegiado por esse curso é apropriado no discurso dos professores-alunos em formação, em seus trabalhos de conclusão. Nas seções seguintes, tentaremos sintetizar os principais resultados da análise e, no fim, esboçar as conclusões. 


\section{A responsividade dos trabalhos de conclusão}

Como vimos, Bakhtin (2010) afirma que todo enunciado sobre um tema responde aos enunciados anteriores sobre o mesmo tema, critica-os, concorda com eles, reelabora-os. Essa definição caracteriza a responsividade, um dos elementos do enunciado analisado neste trabalho. Em geral, os professores-alunos criaram discursos homogeneamente responsivos, ou seja, tanto a dissertação quanto o produto educacional de cada um, componentes do enunciado, acabaram por ser responsivos às mesmas instituições.

$\mathrm{Na}$ primeira dissertação, o professor-aluno 1 está constantemente sendo responsivo aos resultados e aos estudos desenvolvidos sobre testes internacionais, bem como ao referencial metodológico que escolheu adotar. Com frequência, ele cita dados de testes e pesquisas realizadas para fazer comparações de qualidade de ensino e justificar seu trabalho e seu produto. Como é o caso dos dois primeiros capítulos de sua dissertação, onde ele justifica a necessidade e a existência de seu produto através do argumento de que os resultados dos testes mostram o quão deficitário é o ensino de física. Nas palavras do professor-aluno 1:

Historicamente, as provas de Física no vestibular da UFRGS vêm figurando entre as de menor média de acertos. Esse fato evidencia o quanto o ensino de Física vem falhando em formar pessoas capazes de compreender e usar um vocabulário básico de maneira coerente, interpretar e usar equações e fórmulas e, acima de tudo, pensar sobre situações hipotéticas, que constituem a essência dos problemas de Física.

Ainda que o trecho apresentado traga apenas o exemplo do vestibular da UFRGS, ao longo do capítulo o professor-aluno cita outros testes, como o Programme for International Student Assessment (Pisa) e o Third International Mathand Science Survey (TIMSS). Em seu produto educacional, porém, ele acaba sendo responsivo apenas ao referencial metodológico adotado (Projeto Mão na Massa), pois propõe apenas atividades experimentais baseadas nesse referencial em detrimento de todos os outros referenciais citados ao longo do trabalho:

Geralmente, as turmas em que um ensino do tipo "mão na massa" funciona melhor são aquelas nas quais há uma homogeneidade, com a maioria das crianças se situando em um nível aproximadamente igual de aproveitamento.

[...] partindo de modelos nãosequenciais e bastante desorganizados (por vezes consistindo apenas de um desenho sem texto), os relatos individuais da maioria das crianças evoluem gradativamente para um formato no qual há uma sequência de fatos, resultados relativamente organizados e uma discussão na qual uma teoria é proposta realmente com base no fenômeno observado.

Nesse trecho, é possível notar que o professor-aluno 1 não utiliza os referenciais teóricos escolhidos (Piaget, Vygotsky e Vergnaud) para suportar suas discussões, sendo seu discurso totalmente construído sobre dados de sua prática e de suas próprias crenças, que se estruturam, basicamente, no referencial metodológico eleito. 
O professor-aluno 2, na maioria das vezes, constrói seu discurso de forma a torná-lo responsivo ao referencial teórico adotado (teoria da aprendizagem significativa de Ausubel e Novak). Logo na justificativa, fica claro que ele busca sempre se adequar às ideias propagadas pelo referencial teórico assumido, principalmente ao criar um texto que, apesar de implicitamente apresentar um problema oriundo da sala de aula (falta de disposição dos alunos), é construído para dar ênfase ao referencial, relegando para o segundo plano o problema escolar. A seguir, trecho da justificativa do trabalho 2: "Pretende-se desta forma fazer com que o aluno fique mais predisposto a aprender, por isso, além do enfoque histórico, os textos associam os tópicos estudados com situações do cotidiano".

O produto educacional do professor-aluno 2 também é elaborado de modo a ser responsivo ao referencial teórico, já que, ao longo dele, há um diálogo com os constructos da teoria de Ausubel e Novak, como no trecho a seguir: "[...] é característica do material confeccionado abordar, primeiro, temas mais gerais e, depois, conceitos mais específicos. Também, assuntos de um determinado capítulo são frequentemente retomados e revistos em outros capítulos".

No decorrer do capítulo, podemos identificar a voz do referencial teórico escolhido pelo professor-aluno. Ele faz clara alusão à diferenciação progressiva, conceito estruturador da teoria ausubeliana, integrando-o ao discurso sobre seu produto. É possível depreender, então, a apropriação da teoria de Ausubel e Novak, tornando o capítulo responsivo a esse referencial.

Por outro lado, os enunciados do discurso do professor-aluno 3 são, geralmente, responsivos às políticas educacionais. Ele justifica a proposta utilizando premissas e ideias originadas nas políticas educacionais, bem como busca subsídios acadêmicos em trabalhos já realizados para dar materialidade às políticas e, assim, poder dialogar mais facilmente com elas em sua proposta, como ocorre, por exemplo, no seguinte trecho:

[...] se o computador for efetivamente usado para aprendizagem de Física desde as Físicas Gerais a disciplinas específicas, discussões e reflexão sobre seu uso forem feitas em consonância com reflexões sobre outros recursos e estratégias de ensino, as Diretrizes Curriculares estariam sendo atendidas, talvez até de forma mais eficaz.

Então, nos centramos em artigos que mais nos chamaram atenção para apresentar, mesmo que resumidamente, alguns pontos positivos e negativos, vantagens e limitações da utilização de recursos computacionais, além de sugestões de softwares ou metodologias que consideramos serem relevantes e indispensáveis para o ensino de Física quando se pretende promover novas perspectivas apregoadas pelos Parâmetros Curriculares Nacionais do Ensino Médio e quando se pretende atender as diretrizes e resoluções que normatizam os cursos de licenciatura no Brasil.

Parece que houve apropriação do modelo de formação do MPEF na responsividade dos enunciados produzidos pelos três professores-alunos, uma vez que, em nenhum momento, eles são responsivos discursivamente à escola, à comunidade ou às demandas sociais com as quais convivem diariamente.

Ainda que nenhum deles trabalhasse em comunidades de risco ou na 
periferia, seria impossível acreditar que sua sala de aula não tenha nenhum problema que mereça ser discutido. $O$ professor-aluno 1, ao assumir os exames de avaliação nacional e internacional como parâmetro de qualidade da educação, é um exemplo da apropriação do modelo do especialista técnico, que, voltado à eficácia e à eficiência de sua prática para certo objetivo pré-estabelecido por órgãos superiores, acaba se esquecendo do contexto sociocultural que o rodeia. O professor-aluno 2 chega a tangenciar a questão da falta de interesse dos alunos, mas essa demanda está apenas implícita em seu discurso e ainda pode estar sendo usada apenas porque é parte conceitual de seu próprio referencial teórico, escolhido previamente. O professoraluno 3, ao tratar das políticas públicas sem uma maior discussão, apenas porque elas se configuram como as diretrizes nacionais impostas pelos órgãos responsáveis pela educação, também depreende a apropriação desse modelo.

É importante deixar claro que o referencial teórico não seria um entrave se fosse discutido, interpretado e reinterpretado através do problema próprio da escola, e não o contrário, como ocorreu nos trabalhos analisados. Os autores parecem ter adaptado a questão ao referencial teórico que lhes agradava em vez de terem escolhido o mais adequado no sentido de contribuir para a compreensão do que lhes afligia.

\section{A direcionalidade dos trabalhos de conclusão}

Bakhtin (2010) atribui ao enunciado as características de responsividade e direcionalidade; todo enunciado é prenhe de resposta e não resiste em antecipar as do suposto ouvinte, direcionando-se a ele. Nos três trabalhos de conclusão analisados, a direcionalidade voltou-se para a academia e para o público-alvo da proposta dos produtos educacionais, como no trecho a seguir, do trabalho do professor-aluno 3:

De maneira geral as dissertações do Mestrado Profissional em Ensino de Física do nosso Programa de Pós-Graduação apresentam uma descrição sucinta da teoria de aprendizagem que amparou teoricamente o trabalho, indicando particularmente de que modo ela contribuiu à concepção, elaboração e desenvolvimento do material e/ ou experiência didática realizada... A fim de não estender demasiadamente a presente dissertação, tomamos a liberdade de não partir dos fundamentos das teorias de aprendizagem subjacentes, mas ir diretamente a trabalhos da área, bem ancorados teoricamente, que serviram de suporte às nossas pretensões.

O professor-aluno 3 parece entender as regras para que um trabalho seja caracterizado como acadêmico. Entretanto, para burlar uma delas, ele se justifica, tendo em vista uma preocupação com a futura avaliação do orientador e de outros professores, possíveis membros da banca avaliativa. É possível depreender, então, que a direcionalidade desse trecho do enunciado é a academia, percebida de forma imediata na figura do orientador e dos professores integrantes da banca.

De fato, a dissertação configura um documento acadêmico que será apreciado por docentes oriundos desse meio, sejam eles os orientadores (ou orientador), sejam os membros da banca de avaliação. Logo, o fato de essa direcionalidade ocorrer não é surpreendente, mas a inclusão notória de alguns capítulos apenas para cumprir uma demanda da academia parece ultrapassar a adequação do discurso. No trabalho 
do autor 1, por exemplo, ficou claro que os referenciais teóricos foram incluídos somente porque se tratava de uma exigência acadêmica, já que, em nenhum momento, o professor-aluno assume compromisso com esses referenciais:

O objetivo do currículo de Física aqui proposto, portanto, é oferecer aos alunos com idades entre sete e dez anos a possibilidade de vivenciar as situações que podem ser vivenciadas na sua idade, dar os passos que certas crianças podem dar na construção do conhecimento, sem preocupação com rigor teórico ou conceitual.

Nesse trecho, em que o professor-aluno 1 poderia justificar os autores apresentados, ele só traz uma ideia geral, pouco relacionada com todo o suporte teórico indicado. Ainda que ele mencione as idades e que se possa identificar a voz de Piaget, não é possível estabelecer essa relação, pois Piaget, em sua teoria, tenta não se prender tanto a idades reais, mas ao que ele denomina de estágios de desenvolvimento, que compreendem faixas etárias não estanques. Assim, nem a denominação nem a ideia do conceito piagetiano foram apropriadas pelo professor-aluno 1. Consequentemente, não há como afirmar que a voz do teórico aparece nesse discurso.

Essa direcionalidade também aparece nos trabalhos dos professoresalunos 2 e 3 quando eles propõem o emprego de instrumentos de pesquisa, como questionário e entrevista, claramente desenvolvidos para oferecerem dados empíricos e, assim, cumprirem uma demanda acadêmica, já que esses serviram apenas para corroborarem aspectos positivos do produto e da implementação. Além disso, nenhum dos autores fez mudanças significativas ou considerações críticas acerca de sua proposta após a análise dos dados. Ao os tratarem como secundários e apenas como indícios positivos, os professores-alunos 2 e 3 pareceram, de certa forma, desconsiderar as relações e as questões que surgiram no contexto real de sua sala de aula quando da implementação do produto. Consideramos que tal atitude faz parte de uma apropriação discursiva do modelo propagado pelo MPEF, que não está preocupado com as questões reais de sala de aula, mas em atender a exigências dos órgãos de fomento superiores.

\section{A racionalidade técnica nos produtos}

Mesmo que a ideia de elaborar um produto ou um material didático esteja de acordo com o modelo do professor reflexivo, que tem o papel de pesquisar e refletir, com capacidade de resolver criativamente as situações-problema para a realização prática de suas pretensões educativas (CONTRERAS, 2012), devemos nos atentar para a forma como esse produto é elaborado, apresentado e implementado. Nos três trabalhos de conclusão analisados, os autores desenvolveram produtos educacionais e os aplicaram em sala de aula, porém todos eles exibem características da racionalidade técnica, deixando de fora a oportunidade para uma reflexão genuína sobre as questões da escola.

O produto desenvolvido no trabalho 1 é direcionado para que os alunos do Ensino Fundamental tenham acesso a conteúdos de física através de atividades experimentais e cheguem ao Ensino Médio tendo os aprendido. Nas palavras do próprio professor-aluno: 
[...] proponho que a Física seja incluída no currículo do ensino Fundamental desde a primeira série [...], que aprendam a usar as ferramentas e desenvolvam as habilidades necessárias à compreensão da Física [...] ainda em um estágio de desenvolvimento no qual suas percepções pessoais não estejam criticamente sedimentadas e sua curiosidade natural possa ser estimulada e guiada de maneira que eles cheguem à adolescência com uma bagagem mais apropriada à Física do Ensino Médio.

Esse produto é construído por meio do gênero discursivo de manuais e receitas, sendo, assim, impositivo e taxativo no sentido de se apresentar como a única forma de se ter sucesso na área, o que se pode verificar nos trechos a seguir: "Em aulas desse tipo, as atividades propostas não devem ter um plano muito rígido [...]"; "Os professores podem oferecer formulários para autoavaliação [...] essa autoavaliação deve pesar na avaliação que os professores fazem dos projetos".

Essa característica do produto - que determina como, onde e quando devem ser elaboradas as atividades - relacionada com a ideia do professor-aluno 1 de que o ensino de física tem sido um fracasso, após avaliação do desempenho obtido pelos alunos em um exame vestibular, é totalmente compatível com o modelo do especialista técnico. Aceitar um teste quantitativo como parâmetro de qualidade educacional e elaborar todas as atividades com o único propósito de se obter sucesso nesse teste remetem à ideia de que o docente é o grande responsável por todo e qualquer desempenho dos estudantes. Logo, para o professor ser um bom profissional, sua performance deve remontar à visão do expert infalível (CONTRERAS, 2012), ou seja, ele precisa dominar muito bem o conteúdo determinado pelas grades curriculares cobradas nos testes avaliativos.

O produto desenvolvido no trabalho 2 , apesar de ter um estilo linguístico menos impositivo, acaba por reproduzir o modelo dos livros didáticos já existentes no mercado, como ocorre no seguinte trecho:

Lembre-se que a pressão aumenta com a profundidade. Sendo assim, podemos concluir, observando a figura 26, que a pressão sobre o cilindro no ponto B é maior que no ponto A (pois o ponto $\mathrm{B}$ está numa profundidade maior que a de A). Logo, a força associada a essa pressão, exercida pelo líquido no ponto B, é maior que no ponto A. Justamente esta diferença de pressão (e de força) entre os pontos a diferentes profundidades origina o empuxo. [...]

Sabemos que o módulo do empuxo (E) é igual ao valor do peso do líquido deslocado $(P l d)$, ou seja: $\mathrm{E}=P l d=m l d . \mathrm{g}$

A figura à qual o professor-aluno 2 se refere é a de um quadrado aberto na parte superior, imitando um tanque com água, com um retângulo dentro, parecendo um cilindro mergulhado. Essa figura e a abordagem dos conceitos trazida pelo autor são clássicas em livros didáticos, e aparte referente à história da ciência figura apenas como ilustração, contada no início do capítulo através do mito da coroa de Hieron. Assim, a história da ciência, que seria a novidade dessa proposta, é trabalhada somente como coadjuvante para os conceitos. Ainda que o professoraluno 2 busque se informar acerca de uma perspectiva nova de ensino, a história da ciência, é na elaboração e na implementação do produto educacional que notamos 
que seu discurso remonta às ideias propagadas pelos livros didáticos. Todo o aporte teórico que ele apresenta em relação a essa perspectiva acaba não sendo utilizado nem na justificativa da proposta, nem no próprio produto. Dessa forma, ele veste o velho com roupas novas e não foge da ideia da racionalidade técnica.

O produto elaborado pelo professor-aluno 3 busca cumprir uma demanda das políticas públicas por meio da utilização do computador em sala de aula. $\mathrm{O}$ autor aceita, sem questionamentos, diretrizes impostas por documentos educacionais direcionados aos ensinos médio e superior, o que se pode averiguar no seguinte período: “[...] a ênfase do presente trabalho é em atividades experimentais e computacionais a serem desenvolvidas pelos alunos com o objetivo de instigar certas habilidades e competências".

Podemos notar, pelo uso dos conceitos de habilidades e competências, que o professor-aluno além de se apropriar das políticas educacionais para justificar a elaboração da proposta, também utiliza preceitos das políticas como aporte teórico para orientar o desenvolvimento de seu trabalho. O que demonstra que esse professoraluno aceita e compreende as políticas públicas, criadas por especialistas, como orientadoras para que o processo de ensino e aprendizagem ocorra da melhor forma.

Através das análises também foi possível depreender que a utilização de diretrizes curriculares para diferentes níveis de ensino pelo professor-aluno 3 deveu-se provavelmente ao fato de ele considerar que os alunos que chegam ao nível superior não possuem as competências e habilidades que teriam de ter desenvolvido em níveis anteriores. No trecho a seguir, por exemplo, o autor apresenta, de forma explícita, as habilidades e competências retiradas dos Parâmetros Curriculares Nacionais voltados para o Ensino Médio desenvolvidas através de atividades propostas nas diretrizes do Ensino Superior.

[...] os alunos trabalharam no sentido de desenvolver habilidades e competências sugeridas pelos PCN $+[. .$.$] realizando diversas ações sugeridas nas Diretrizes Curriculares Nacionais$ para a Formação de Professores e nas Diretrizes Curriculares para o curso de Física.

A aceitação das políticas educacionais sem maior discussão remonta a uma das principais características do modelo do especialista técnico, assim como o conteudismo dos produtos 1 e 2 e a imposição da prática através do um discurso de autoridade e salvacionista do produto 1.

Fica claro então que os três produtos possuem muitos traços da racionalidade técnica, provavelmente por terem sido criados à luz do modelo do especialista técnico difundido implícita e explicitamente pelo MPEF.

\section{A influência dos contextos individuais}

Foi possível perceber que os contextos extraverbais individuais se mostraram decisivos nas escolhas dos professores-alunos, seja do nível educacional para qual se dirige o produto ou do referencial teórico adotado.

No primeiro trabalho, o professor-aluno 1 é extremamente influenciado a escolher referenciais estrangeiros em detrimento dos referenciais nacionais, provavelmente porque trabalha em uma escola internacional, onde os seus colegas são oriundos de países de língua inglesa. Nas palavras dele: "O interesse e a 
curiosidade gerados pelo contato diário que tenho tido com professores de outros países (principalmente Nova Zelândia e Austrália) foi outro fator que pesou, em muito, para o fato de eu ter procurado referências fora do Brasil."

No segundo trabalho, o professor-aluno 2 privilegia o referencial teórico, atribuindo à academia um prestígio e status que acredita existirem. Esse autor enquanto realizava o MPEF do IF da UFRGS também realizava um mestrado na área das engenharias em uma universidade particular. Sua alta apreciação pelo meio acadêmico e o ideal de que a academia é hierarquicamente superior à escola básica remontam à característica do especialista técnico e nos auxilia na compreensão de sua escolha em atrelar o seu produto e dissertação às demandas de um referencial teórico aceito e prestigiado na área de ensino de física.

No terceiro trabalho, o contexto individual parece ter influenciado o professor-aluno 3 na escolha do nível de ensino para o qual direcionaria seu produto educacional. Ele já trabalhava com monitoria em uma universidade particular e realizava uma segunda graduação por essa mesma universidade, o que pode tê-lo influenciado nessa escolha. O professor-aluno 3 é o único que elabora seu trabalho na linha de pesquisa de um dos seus orientadores. A escolha por seu referencial teórico pode ter sido influenciada pelo contexto extraverbal da orientação, já que mesmo que o orientador seja designado conforme as ideias e projeções do professoraluno assim que ingressa no MPEF, os ajustes teóricos são feitos posteriormente.

\section{CONSIDERACְÕES FINAIS}

Muitos dos trabalhos encontrados na revisão de literatura sobre a formação continuada no Brasil ou em outros países atribuem aos professores a responsabilidade sobre a melhora da qualidade da educação. Essa melhora, supostamente adquirida através da formação, visa a vários objetivos, e alguns deles tiveram eco em nosso trabalho.

Os trabalhos de conclusão analisados buscavam apresentar propostas que tinham o intuito de renovar questões didáticas e metodológicas na prática docente, assim como os autores de grande parte dos trabalhos revistos (DARROZ et al., 2013; CHAILE; JAVI, 2013). Assumir as demandas governamentais ou os testes de avaliação discente como parâmetro de qualidade, tal qual fazem o professoraluno 1 e o professor-aluno 3, também é a atitude discursiva de autores da área (BAPTISTA; FREIRE, 2011; LAIUS; RANNIKMÄE, 2011). Implicitamente, esses trabalhos acabam por responsabilizar, de forma exclusiva, a prática docente pelo bom desempenho dos alunos.

Outra tendência encontrada na revisão realizada foi o modelo de prática e formação eleito pela maioria dos autores: a reflexão sobre a prática - cada autor utilizou uma nomenclatura distinta (RAMOS; LIMA; ROCHA FILHO, 2009; AMORIM; SOUZA; TRÓPIA, 2010; LOPES et al., 2011; POMBO; COSTA, 2009). No entanto, apesar de esse modelo ter alto índice de aceitação pelos pesquisadores, o de viés tecnicista parece ainda não ter sido superado nos processos formativos (NERY; MALDANER, 2012; OSTERMANN; REZENDE, 2009; SCHÄFER; OSTERMANN, 2013a, 2013b). Schäfer e Ostermann (2013a, 2013b), 
ao estudarem o mesmo MPEF que é objeto de pesquisa deste trabalho, afirmaram que os professores egressos desse curso reproduzem em sua prática o modelo do especialista técnico. Analisando os discursos produzidos no contexto de formação, e não de sala de aula, como fizeram Schäfer e Ostermann (2013a, 2013b), notamos que, ainda que o MPEF do IF da UFRGS exija a construção de um produto educacional, questão que o aproximaria do modelo do profissional reflexivo, a maneira como a construção e a elaboração desse material são realizadas indica apropriação da racionalidade técnica. Até mesmo o professor-aluno 2, que dá certa liberdade aos colegas docentes na implementação de sua proposta, supõe que sua apostila por si só possa atrair a atenção dos estudantes e resolver o problema da falta de interesse na física. Além disso, esse autor não buscou um suporte epistemológico para seu trabalho, deixando o referencial sobre história da ciência apenas como pano de fundo para a apresentação do conteúdo de física. Assim, pudemos notar também no trabalho do professor-aluno 2 maior aproximação com o discurso da racionalidade técnica do que com o do professor-reflexivo.

Um ponto curioso na revisão de literatura feita foi o fato de apenas artigos internacionais (INZUNZA; ASSAÉL; SCHERPING, 2011; NZAU; LOPES; COSTA, 2012) criticarem as ações governamentais. Enquanto, para esses autores, as ações são compensatórias, administrativas e pedagógicas, sem demandarem maior preocupação com as condições educativas reais de cada país ou com a modificação de elementos estruturais essenciais, que atingiriam as desigualdades econômicas, sociais e culturais, os professores-alunos do MPEF parecem, discursivamente, concordar com as políticas educacionais brasileiras à medida que se apropriam delas de forma acrítica em seus trabalhos. Esse fato corrobora a conclusão a que havíamos chegado na síntese crítica da revisão: a área de pesquisa em ensino de ciências no Brasil não está, majoritariamente, preocupada em analisar e tecer críticas às políticas impostas pelo governo, o que parece ser o caso dos orientadores dos trabalhos analisados, membros dessa comunidade.

Em nossa revisão, inferimos que a área está muito mais voltada à criação de propostas e à discussão e à avaliação das estratégias utilizadas, o que encontrou reflexos em nosso estudo. As ferramentas computacionais empregadas pelo professor-aluno 3 e os elementos da história da ciência usados pelo 2 não são novidade na área e aparecem em vários trabalhos encontrados na literatura (MOREIRA; MASSONI, 2009; SANTOS et. al., 2012).

Após realizarmos nossa pesquisa, constatamos que o MPEF do IF da UFRGS está na contramão da indicação de muitos estudiosos, que afirmam que a solução para que haja impacto real da formação continuada sobre a vida escolar é que a realidade docente figure como protagonista nesse processo formativo (LANGHI; NARDI, 2012). Analisando três trabalhos produzidos nesse curso, concluímos que a elaboração e a implementação do produto educacional pelos professores-alunos está totalmente de acordo com o contexto extraverbal, considerado, prioritariamente, a proposta do MPEF, que privilegia o modelo de formação do especialista técnico. Esse desconsidera qualquer aspecto sócio-histórico cultural ligado à realidade escolar, concentrando-se na prática para a obtenção de objetivos fixos pré-estabelecidos. Dentro desse contexto, também o fato de o MPEF exigir a elaboração de um produto educacional e 
de uma dissertação com regras pré-definidas obriga os professores-alunos a estabelecerem forte relação de direcionalidade discursiva com o meio acadêmico do programa. E, à medida que esse discurso privilegia o modelo do especialista técnico, influencia os trabalhos de conclusão, fazendo com que eles fiquem impregnados de características racionalistas técnicas.

É interessante notar que o modelo da racionalidade técnica se refletiu nos trabalhos analisados, apesar de os contextos extraverbais individuais no âmbito institucional serem bem diferentes no que diz respeito à orientação acadêmica e às escolhas temáticas feitas pelos professores-alunos.

Em relação às conjunturas externas, caberia aqui dar continuidade ao estudo, procurando investigar se a visão educacional da racionalidade técnica já se mostrava compatível com os contextos de trabalho e de formação (inicial) do professor, permitindo que ele lidasse com esse discurso como algo conhecido e já aceito, ou se não havia essa compatibilidade e o professor precisou aceitar uma perspectiva distinta apenas para conseguir lograr reconhecimento acadêmico.

De qualquer maneira, este estudo nos mostrou como o discurso é restringido no contexto educacional estudado e o quanto se deixa de fora, em termos de perspectivas formativas e de educação, em um curso de MP nos moldes do MPEF da UFRGS. Diante dos nossos resultados, consideramos que cursos de mestrado profissional em ensino com essas características precisariam de um movimento de abertura, que incorporasse uma variedade de discursos. Os modelos de professor reflexivo e de professor intelectual crítico, por exemplo, poderiam arejar as disciplinas, as discussões teóricas do curso e os produtos educacionais a serem elaborados pelos professores-alunos. Assim, algumas questões que são naturalizadas, como a aceitação incondicional das políticas educacionais nacionais, teriam condições de ser discutidas, e os professoresalunos teriam a possibilidade de repensar criticamente sua prática.

O primeiro passo para efetuar essa mudança seria elaborar um currículo que não privilegiasse a hierarquia prevista por Contreras (2012) no modelo do especialista técnico. Esse currículo poderia ser concebido de modo horizontal, dando igual ênfase às disciplinas de conteúdo específico e aplicado e às de cunho pedagógico, social e político, e não necessariamente ele seria estanque, mas, sim, moldável às demandas dos docentes e construído ao longo da própria formação.

Outro aspecto que poderia ser alterado no MPEF (e em outros cursos com as mesmas características) é a própria dinâmica do curso, através da estipulação de novas maneiras de justificar a elaboração dos produtos. A aproximação entre a escola e a universidade, segundo Zeichner (1993), seria uma forma de aumentar a capacidade docente de enfrentar a complexidade, as incertezas e as injustiças na escola e na sociedade, preparando o docente para ter uma atitude mais reflexiva sobre os processos educativos e as condições sociais que o influenciam. O importante, para que houvesse uma mudança real, seria buscar na escola os problemas vigentes e moldar os referenciais teóricos e metodológicos conforme a real necessidade do docente, e não o contrário, como vimos na análise realizada. $\mathrm{Na}$ realidade, a exigência de um produto educacional elaborado e implementado, como foi instituído pelo MPEF, poderia ser repensada. A ideia de uma estratégia ou de uma proposta salvacionista, que modifique por si só a qualidade da educação 
remonta apenas à visão racionalista técnica do ensino que é propagada pelo modelo do especialista técnico. Se o programa estiver interessado em mudanças que possam romper com esse modelo, o trabalho de conclusão não poderá ter ranços do racionalismo técnico, devendo ser elaborado e implementado visando, principalmente, ser responsivo à realidade escolar.

Esperamos que a análise realizada possa auxiliar cursos de MP que pretendam se posicionar criticamente em relação ao modelo do especialista técnico. As questões aqui discutidas, a proposta de curso do MPEF, o currículo e, sobretudo, a forma como o produto educacional é elaborado e implementado podem contribuir para propostas que busquem privilegiar outros modelos formativos.

\section{NOTAS}

${ }^{1} \mathrm{~A}$ área de ensino de ciências e matemática da CAPES sofreu uma alteração em 2012, desaparecendo enquanto tal e passando a integrar uma área maior, denominada área de Ensino, que passou a abrigar os programas de pós- graduação em ensino de todas as disciplinas.

${ }^{2}$ Por limitação de espaço citaremos apenas os artigos mais representativos das ideias comentadas.

${ }^{3}$ Autor pertencente ao chamado Círculo de Bakhtin, grupo multidisciplinar de intelectuais russos que se reuniam regularmente entre 1919 e 1929. Há, inclusive, discussões e incertezas acerca da autoria de alguns textos produzidos pelo Círculo, como o caso do livro Marxismo e Filosofia da Linguagem, que, inicialmente, foi assinado por Voloshinov, mas, posteriormente, foi atribuído ao próprio Bakhtin.

${ }^{4}$ Disponível em: <http://www.if.ufrgs.br/ppgenfis/index.php.>. Acesso em: 8 dez. 2014.

${ }^{5}$ Disponível em: <http://www.if.ufrgs.br/ppgenfis/index.php.>. Acesso em: 8 dez. 2014.

${ }^{6}$ Dados de 8 de dezembro de 2014.

${ }^{7}$ Parte considerável desta seção é constituída de uma análise da proposta inicial do curso de MPEF da UFRGS, apresentada no XV Encontro de Pesquisa em Ensino de Física, realizado em 2014, em Maresias. Esse estudo teve como objetivo investigar os compromissos formativos do curso e, assim, delinear a formação proporcionada.

\section{REFERÊNCIAS}

AMORIM, F.; SOUZA, C. P.; TRÓPIA, G. Interdisciplinaridade, contextualização e pesquisa-ação: influências de um curso de formação continuada de professores de Ciências na prática docente. Atos de Pesquisa em Educação, v. 5, n. 2, p. 189-208, maio/ago., 2010.

BAKHTIN, M. M. Questões de literatura e de estética: A teoria do romance. 5. ed. São Paulo: Hucitec, 2002. The Dialogic Imagination. 17 $7^{\text {th }}$. ed. Texas: University of Texas Press, 2008.

. Estética da criação verbal. 5. ed. São Paulo: WMF; Martins Fontes, 2010.

BAPTISTA, M. L. M.; FREIRE, A. M. V. L. M. S. Contributo do trabalho colaborativo para o desenvolvimento profissional de professores de Física e Química. Nuances: Estudos sobre Educação, 
v. 19, n. 20, p. 16-30, maio/ago. 2011.

CHAILE, M. O.; JAVI, V. M. Formacion docente en servicio y su recurrencia a material multemedia para enseñarlas energias renovables. Revista Eletrônica de Educação, São Carlos, v. 7, n. 2, p. 381-398, 2013. CONTRERAS, J. A autonomia de professores. 2. ed. São Paulo: Cortez, 2012.

DARROZ, L. M. et al. Mapas conceituais como recurso didático na formação continuada de professores dos primeiros anos do Ensino Fundamental: um estudo sobre conceitos básicos de astronomia. Revista Brasileira de Ensino de Ciências e Tecnologia, Ponta Grossa, v. 6, n. 3, p. 82-105, set./dez. 2013.

INZUNZA, J.H; ASSAÉL, J.B. ; SCHERPING, G.V. Formación docente inicial y en servicio en Chile. Revista Mexicana de Investigación Educativa, Ciudad de Mexico, v. 16, n. 48, p. 267-292, enero-feb. 2011. LAIUS, A.; RANNIKMÄE, M. Impact on student change in scientific creativity and socio-scientific reasoning skills from teacher collaboration and gains from professional in-service. Journal of Baltic Science Education, Siauliai,v. 10, p. 127-137, 2011.

LANGHI, R.; NARDI, R. Trajetórias Formativas Docentes: buscando aproximações na bibliografia sobre formação de professores. Alexandria: Revista de Educação em Ciências e Tecnologia, Florianópolis, v. 5, n. 2, p. 7-28, set. 2012.

LOPES, I. S. et al. Estudos coletivos de educação ambiental como instrumento reflexivo na formação continuada de professores de Ciências em espaços educativos formais e não-formais. Revista Electrónica de Enseñanza de las Ciencias, v. 10, n. 3, p. 516-530, 2011.

LORENZO, M. G. El modelo de integración multinivel para la formación en servicio del profesorado. Revista Electrónica de Enseñanza de las Ciencias, v. 7, n. 3, p. 597-613, 2008.

MOREIRA, M. A.; MASSONI, N. T. Física de partículas y visiones epistemológicas contemporâneas en la formación post graduada de profesores de Física. Experiências em Ensino de Ciências, Cuiabá, v. 4, n. 1, p. 57-64, 2009.

NERY, B. K.; MALDANER, O. A. Formação continuada de professores de química na elaboração escrita de suas aulas a partir de um problema. Revista Electrónica de Enseñanza de las Ciencias, v. 11, n. 1, p. 120-144, 2012.

NZAU, D. K.; LOPES, J. B.; COSTA, N. Formação continuada de professores de física, em Angola, com base num modelo didático para o campo conceptual de força. Revista Brasileira de Ensino de Física, São Paulo, v. 34, n. 3, p. 3402/1 - 3402/13, 2012.

OSTERMANN, F.; REZENDE, F. Projetos de desenvolvimento e de pesquisa na área de Ensino de Ciências e Matemática: uma reflexão sobre os Mestrados Profissionais. Caderno Brasileiro de Ensino de Física, Florianópolis, v. 26, n. 1, p. 66-80, abr. 2009.

POMBO, L.; COSTA, N. Avaliação do impacto de cursos de mestrado nas práticas profissionais de professores de Ciências: exemplos de boas práticas. Investigações em Ensino de Ciências, Porto Alegre, v. 14, n. 1, p. 83-99, 2009.

RAMOS, M. G.; LIMA, V. M. R.; ROCHA FILHO, J. B. A Pesquisa como Prática na Sala de Aula de Ciências e Matemática: um olhar sobre dissertações. Alexandria: Revista de Educação em Ciências e Tecnologia, Florianópolis, v. 2, n. 3, p. 53-81, nov. 2009.

SANTOS, S. R. M et al. Didáticas específicas, novas tecnologias e formação de professores para o ensino de Ciências na baixada fluminense: a experiência do mestrado profissional da Universidade do Grande Rio. Revista Brasileira de Pós Graduação, Brasília, v. 9, n. 16, p. 115-138, abr. 2012.

SCHÄFER, E. D. A. Impacto do Mestrado Profissional em Ensino de Física da UFRGS na prática docente: um estudo de caso. 2013. 338 f. Tese (Doutorado em Ensino de Física) - Programa de Pós-Graduação em Ensino de Física, Instituto de Física, Universidade Federal do Rio Grande do Sul, Porto Alegre, 2013.

SCHÄFER, E. D. A.; OSTERMANN, F. O impacto de um Mestrado Profissional em Ensino de 
Física na prática docente de seus alunos: uma análise bakhtiniana sobre os saberes profissionais. Ensaio: Pesquisa em Educação em Ciências, Belo Horizonte, v. 15, n. 2, p. 87-103, maio/ago. 2013a. SCHÄFER, E. D. A.; OSTERMANN, F. Autonomia profissional na formação de professores: uma análise de entrevistas realizadas num mestrado profissional em ensino de física. Revista Electrónica de Enseñanza de las Ciencias,v. 12, n. 2, p. 287-312, 2013 b.

SLONGO, I. I. P.; DELIZOICOV, N. C.; ROSSET, J. M. A formação de professores enunciada pela pesquisa na área de Educação em Ciências. Alexandria: Revista de Educação em Ciências e Tecnologia, Florianópolis, v. 3, n. 3, p. 97-121, nov. 2010.

VENEU, A. A.; FERRAZ, G.; REZENDE, F. Análise de discursos no ensino de ciências: considerações teóricas, implicações epistemológicas e metodológicas. Ensaio: Pesquisa em Educação em Ciências, Belo Horizonte, v. 17, n. 1, p. 126-149, 2015.

VOLOSHINOV, V. N. A estrutura do enunciado. Tradução de Ana Vaz, para fins didáticos. Texto de circulação acadêmica, 1981. [Texto original publicado na revista Literaturnja Ucëba, v. 3. p. 65-87, 1930.] ZEICHNER, K. M. A formação reflexiva do professor: ideias e práticas. Lisboa: Educa, 1993.

Data de recebimento: 28/04/2015

Data de Aprovação: 21/06/2016

Data da versão final: $11 / 07 / 2016$

\section{Contato:}

Josiane de Souza

Avenida Ozório de Almeida Taques, 517

Bloco A1 Ap 32, Bairro Centro.

Telêmaco Borba, PR - Brasil

CEP: $84.261-680$

josiane.souza@ufrgs.br 
